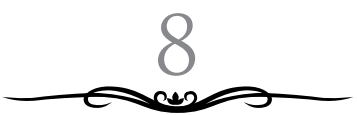

\title{
MEWUJUDKAN KEPUASAN PEMUSTAKA MELALUI MANAJEMEN PEMANFAATAN MEDIA SOSIAL
}

\author{
Taufikin \\ STAIN Kudus, Jawa Tengah, Indonesia \\ taufikin@stainkudus.ac.id
}

\begin{abstract}
The proliferation of social media in cyberspace communication among humans lately still dominated by information that the basic of science is still limited, on the other side the reader complaints increased because of limited library services from various aspects. This is the rationale for incorporating libraries into social media. The goal is the realization of reader satisfaction, especially utilizing the advancement of internet technology, namely social media. This study included study of library research using empirical-based qualitative approach, data collection method with observation, interview and documentation, then analyzed descriptively. The result is that the Library can facilitate its service with social media that is managed by applying the functions of management: planning, organizing, actuating, monitoring and evaluation. The Library can Implementate by done include: 1) selection of appropriate social media 2) organizing staff/ human resources, facilities, time and coordination 3) implementation of library services with social media 4) supervise service 5) evaluate the level of reader satisfaction.
\end{abstract}

Keyword: Satisfaction Reader, Management, Social Media 


\begin{abstract}
Abstrak
Menjamurnya media sosial dalam komunikasi dunia maya antar manusia akhir-akhir inimasih didominasi informasi yang dasar keilmuannya masih terbatas, di sisi lain keluhan pemustaka meningkat karena terbatasnya pelayanan perpustakaan dari berbagai aspek. Hal ini mejadi dasar pemikiran untuk memasukkan perpustakaan ke dalam media sosial. Tujuannya adalah terwujudnya kepuasan pemustaka, khususnya memanfaatkan kemajuan teknologi internet, yaitu media sosial. Kajian ini termasuk kajian library research dengan menggunakan pendekatan kualitatif berbasis empiris, metode pengumpulan data dengan observasi, wawancara dan dokumentasi, kemudian dianalisis secara deskriptif. Hasilnya bahwa Perpustakaan dapat mempermudah pelayanannya dengan Media sosial yang dikelola dengan menjalankan fungsi manajemen perencanaan, pengorganisasian, penggerakkan, pengawasan dan evaluasi. Penerapan yang dapat dilakukan oleh perpustakaan antara lain: 1) pemilihan media sosial yang tepat 2) mengorganisasikan staff/SDM, sarana, waktu dan koordinasi 3) pelaksanaan penerapan layanan perpustakaan dengan media sosial 4) melakukan pengawasan layanan 5) melakukan evaluasi terhadap tingkat kepuasan pemustaka.
\end{abstract}

Kata Kunci: Kepuasan Pemustaka, Manajemen, Media Sosial

\title{
A. Pendahuluan
}

Media sosial semakin merajai pola komunikasi masyarakat dunia. Dunia semakain sempit karena komunikasi yang semakin mudah dan bebas karena adanya media sosial. Informasi yang diperoleh dari Media sosial pun beragam. Namun kebanyakan informasi maupun komunikasi dari media sosial yang terpantau masih didominasi oleh tukar menukar informasi antar pengguna media sosial, curhat, status, maupun berita-berita yang sedikit sekali menjangkau ranah keilmuan.

Bahkan media sosial dalam beberapa kasus memberikan dampak negatif seperti terjadinya kriminalitas, kekerasan dan pelanggaran Undang-undang lainnya. Di sisi lain, perpustakaan yang masih melayani pemustaka dengan cara datang langsung semakin banyak, sehingga muncul berbagai macam keluhan seperti tidak 
kebagian buku karena terbatas jumlahnya, ruangan yang semakin terasa sempit, waktu yang terbatas dan lain-lain.

Berdasarkan hal tersebut di atas, muncul sebuah pemikiran bahwa saatnya perpustakaan mengambil peran penting sebagai subyek/ ataupun medium yang mampu mengubah media sosial menjadi mesin pemroduksi ilmu pengetahuan yang muncul setiap saat melalui media sosial. Ilmu pengetahuan baik berupa buku-buku, Jurnal dan karya ilmiah lainnya yang selama ini hanya bisa diakses dari dalam ruangan perpustakaan yang amat terbatas, dihubungkan atau ditampilkan ke dunia media sosial sehingga akses lebih mudah, cepat dan dapat dilakukan kapan saja dan dari mana saja dengan jaringan internet yang ada.

Tujuan utama dalam pelayanan perpustakaan adalah kepuasan pemustaka (pelanggan). Strategi dalam mencapai kepuasan pelanggan perpustakaan dapat dilakukan melalui berbagai cara. Beberapa diantaranya adalah manajemen perpustakaan yang kontemporer atau mengikuti perkembangan zaman (teknologi). Selain sarana dan prasarana yang representatif, promosi manajemen perpustakaan melalui website dan juga media sosial amat diperlukan, untuk mempermudah mencapai tujuan, yaitu kepuasan pemustaka (mahasiswa). Alternatif yang dapat diterapkan dalam mencapai kepuasan pemustaka adalah mengelola pelayanan perppustakaan melalui media sosial, shingga perpustakaan menjadi seperti dalam genggaman pemustaka.

Perpustakaan sebagai pusat sebuah institusi sebagai pusat yang dibangun untuk kepentingan masyarakat. Pengorganisasian informasi ini dilakukan karena adanya kebutuhan akan informasi yang mudah bagi pihak yang membutuhkan baik perorangan maupun kelompok. Oleh karena itu, layanan yang dilakukan selalu berorientasi pada masyarakat, sebagai pengguna informasi. Kepuasan pengguna merupakan petunjuk utama bagi pelaksana pengorganisasian informasi. Dalam perkembangannya, kebutuhan pengguna informasi juga berubah-ubah baik dari segi keragaman isi maupun aksesnya. Mobilisasi manusia yang makin cepat menimbulkan tuntutan hidup yang kian besar dan beragam. Perubahan pola hidup masyarakat ini mengubah pula karakter kebutuhan informasi mereka. Pengguna 
cenderung membutuhkan semakin banyak informasi untuk mengimbangi aktivitasnya, namun waktu dan energi mereka terbatas untuk menelusuri informasi tersebut. Efisiensi dan efektifitas menjadi pertimbangan utama pengguna dalam memenuhi kebutuhannya.

Dalam hal ini, konsep layanan informasi yang bersifat konvensional, yang hanya menunggu pengguna datang harus dikembangkan ke arah yang lebih aktif. Perpustakaan harus bertransformasi atau menyesuaikan diri dengan perkembangan ilmu pengetahuan dan teknologi yang ada. Kepuasan pengguna merupakan barometer keberhasilan suatu perpustakaan. Berdasarkan International Organization for Standardization atau ISO 11620-1998 kepuasan pengguna menempati urutan pertama dari 29 (dua sembilan) indikator untuk pengukuran kinerja perpustakaan. ${ }^{1}$ Kepuasan dapat diartikan sebagai sesuatu keadaan dalam diri seseorang atau sekelompok orang yang telah berhasil mendapatkan sesuatu yang dibutuhkan dan diinginkannya.

Kualitas pelayanan yang diterima pengguna informasi mempengaruhi perilaku dan loyalitas di waktu yang akan datang. perpustakaan yang baik dapat diukur dari keberhasilannya dalam menyajikan pelayanan yang bermutu kepada pengguna. Semakin baik pelayanannya, semakin tinggi penghargaan yang diberikan kepada perpustakaan.

Beberapa perguruan tinggi mengalami beberapa kendala yang perlu segera dicarikan solusi yang elegan. Kendala tersebut antara lain sarana gedung yang belum mencukupi kebutuhan jumlah mahasiswa, jumlah buku dalam satu judul yang terbatas, minat mahasiswa ke perpustakaan baik untuk membaca maupun meminjam buku yang tergolong masih rendah, dan pengelolaan website yang terhubung dengan media sosial juga belum maksimal.

Maka dari itu, agar kepuasan pelanggan (mahasiwa) berupa kemudahan dan kecepatan mendapatkan informasi dari perpustakaan tercapai, menyusun strategi agar dapat menjadikan perpustakaan yang kecil sekalipun dapat diakses dari seluruh penjuru dunia. Alternatif hlm. 61-67.

${ }^{1}$ Purnomowati, S.. Mengukur kinerja perpustakaan. BACA 252000 (3\&4), 
yang memungkinkan adalah manajemen yang baik dan terukur melalui pengelolaan website dan media sosial.

\section{B. Pembahasan}

\section{Kepuasan Pemustaka (Pelanggan)}

Pelanggan adalah semua orang yang menuntut kita atau lembaga untuk suatu standar kualitas tertentu, dan karena itu akan berpengaruh padaperformansi lembaga. ${ }^{2}$ Pada dasarnya kepuasan pelanggan dapat didefinisikan secara sederhana sebagai suatu keadaan dimana kebutuhan, keinginan, dan harapan pelanggan dapat terpenuhi melalui produk yang dikonsumsi. ${ }^{3}$ Kepuasan pelanggan merupakan tanggapan perilaku, berupa evaluasi pelanggan terhadap suatu barang atau jasa yang dirasakannya dibandingkan dengan harapan atau ekspektasi terhadap produk atau jasa tersebut. Banyak pakar yang memberikan definisi mengenai kepuasan pelanggan.

Engel mengungkapkan bahwa kepuasan pelanggan merupakan evaluasi pengguna jasa sebuah lembaga, dimana alternatif yang dipilih sekurang-kurangnya memberikan hasil (out come) sama atau melampaui harapan pelanggan, sedangkan ketidakpuasan timbul apabila hasil yang diperoleh tidak memenuhi harapan pelanggan. Sedangkan pakar pemasaran, Kotler menandaskan bahwa kepuasan pelanggan adalah tingkat perasaan seseorang setelah membandingkan kinerja atau hasil yang ia rasakan dibandingkan dengan harapannya. ${ }^{4}$ Karena kepuasan pelanggan sangat tergantung pada persepsi dan ekspektasi mereka, kita sebagai lembaga yang memasok produk perlu mengetahui beberapa faktor yang mempengaruhi hal tersebut. Faktorfaktor yang mempengaruhi persepsi dan harapan pelanggan adalah sebagai berikut:

1. Kebutuhan dan keinginan yang berkaitan dengan hal-hal yang dirasakan pelanggan. hlm. 33 .

${ }^{2}$ Vincent Gaspers, Total Quality Management, (Jakarta: Gramedia, 2008), 2010), hlm. 48.

${ }^{3}$ M. Nur Nasution, Manajemen Mutu terpadu, (Bogor: Ghalia Indonesia,

${ }^{4}$ M. Nur Nasution, Manajemen Jasa terpadu (Total Service Management), (Bogor: GhaliaIndonesia, 2004), hlm. 104. 
2. Pengalaman masa lalu ketika mengkonsumsi prosuk dari perusahaan maupun pesaing-pesaingnya.

3. Pengalaman dari teman-teman, dimana mereka akan menceritakan pengalaman yang mereka dapatkan kepada teman-teman mereka.

Kepuasan pelanggan mencakup perbedaan antara harapan dan kinerja atau hasil yang dirasakan. Karena pelanggan adalah orang yang menerima hasil pekerjaan seseorang, maka pelangganlah yang menentukan kualitas suatu produk. Ada beberapa unsur penting dalam kualitas yang ditetapkan pelanggan, yaitu sebagai berikut:

1. Pelanggan harus merupakan prioritas utama organisasi

2. Pelanggan yang dapat diandalakan merupakan pelanggan yang paling penting

3. Kepuasan pelanggan dijamin dengan menghasilkan produk berkualitas tinggi dan perbaikan terus-menerus.

Kualitas layanan dinilai berdasarkan persepsi konsumen yang membandingkan harapan untuk menerima layanan dan pengalaman sebenarnya atas layanan yang diterima. Jika harapan tidak terpenuhi maka kepuasan akan berkurang, sebaliknya jika harapan terpenuhi maka kualitas layanan dipersepsikan menjadi kepuasan. Kualitas layanan yang memuaskan akan memberikan gambaran yang baik bagi lembaga, sebaliknya bila layanan mengecewakan akan menciptakan kesan yang buruk bagi penyedianya. Pihak lembaga atau perusahaan harus berusaha semaksimal mungkin agar dapat memeberikan layanan prima sehingga pelanggaan akan tetap setia menggunakan jasanya dan tidak berpindah kelain hati. Dalam hal ini, karyawan memiliki peran sangat penting.

Kunci membentuk fokus kepuasan pelanggan adalah menempatkan karyawan untuk berhubungan langsung dengan pelanggan dan memberdayakan karyawan untuk mengambil tindakan yang diperlukan untuk memuaskan para pelanggan. Jadi interaksi antara karyawan dan pelanggan merupakan unsur yang sangat penting dalam pembentukan fokus pada pelanggan. 
Di dalam memberikan jasa pelayanan yang baik kepada pelanggan, terdapat lima kriteria penentu kualitas jasa pelayanan yaitu keandalan, keresponsifan (ketanggapan), keyakinan, empati, serta berwujud. ${ }^{5}$ Ada beberapa penyebab utama tidak terpenuhinya harapan pelanggan, diantaranya adalah:

1. Pelanggan keliru mengkomunikasikan jasa yang diinginkan

2. Miskomunikasi rekomendasi mulut ke mulut

3. Kinerja dan sikap karyawan jasa yang buruk

4. Miskomunikasi penyedia jasa oleh pesaing

Diantara beberapa faktor penyebab tersebut, ada yang bisa dikendalikan oleh penyedia jasa. Dengan demikian, penyedia jasa bertanggung jawab untuk meminimumkan miskomunikasi dan misinterpretasi yang mungkin terjadi dan menghindarinya dengan cara merancang jasa dan mudah dipahami dengan jelas. Dengan hal ini, penyedia jasa harus mengambil inisiatif agar ia dapat memahami dengan jelas intruksi kebutuhan dari pelanggan dan pelanggan mengerti benar apa yang akan diberikan.

Sebelum menggunakan suatu jasa, pelanggan sering memiliki empat skenario jasa yang berbeda (dalam benaknya) mengenai apa yang akan dialaminya, yaitu jasa ideal, jasa yang diantisipasi/diharapkan, jasa yang selayaknya diterima, jasa minimum yang dapat ditoleransi. Kepuasan pelanggan bisa diharapkan dari keempat skenario tersebut. Sebagaimana telah dijelaskan, harapan membentuk kepuasan apabila "jasa minimum yang dapat ditoleransi”, yang diharapkan ternyata sama dengan atau bahkan melampaui harapan tersebut, maka akan timbul kepuasan. Sebaliknya, jika yang diharapkan tersebut tidak terpenuhi maka yang terjadi adalah ketidakpuasan.

\section{a. Strategi Kepuasan Pelanggan}

Upaya mewujudkan kepuasan pelanggan total bukanlah hal yang mudah. Bahkan Muide dan Cottam (1993) menyatakan bahwa kepuasan pelanggan total tidak mungkin tercapai sekalipun hanya untuk sementara waktu. Namun, upaya perbaikan atau penyempurnaan kepuasan dapat dilakukan dengan berbagai strategi. Pada prinsipnya,

${ }^{5}$ M. Nur Nasution, Manajemen Mutu Terpadu,hlm, 69. 
strategi kepuasan pelanggan akan menyebabkan para pesaing harus bekerja keras dan memerlukan biaya tinggi dalam usahanya merebut pelanggan sebuah lembaga.

Kepuasan pelanggan merupakan strategi jangka panjang yang membutuhkan komitmen, baik menyangkut dana maupun sumber daya manusia. Ada beberapa strategi yang dapat dipadukan untuk meraih dan meningkatkan kepuasan pelanggan, antara lain: ${ }^{6}$

\section{b. Strategi superior customer service}

Yaitu menawarkan pelayanan yang lebih baik dibandingkan lembaga lain. Dalam hal ini perpustakaan harus memberikan pelayanan yang lebih baik dari pada pelayanan perpustakaan yang ada disekitarnya. Untuk meningkatkan kepuasan pelanggan, lembaga dapat mengembangkan augmented service terhadap core servise-nya, misalnya dengan merancang garansi tertentu dengan memberikan pelayanan transaksi yang baik. Pelayanan purna transaksi ini harus pula menyediakan media yang efisien dan efektif untuk menangani keluhan. Meskipun hanya membiarkan konsumen melepaskan emosinya, itu sudah cukup baik, minimal persepsi terhadap kepuasan dan kewajiban akan mengingat jika lembaga mengakui kesalahannya dan menyampaikan permohonan maaf, serta memberikan semacam ganti rugi yang berharga bagi konsumen.

\section{c. Strategi unconditional service guarantees atau extraordinary guarantees}

Strategi ini berintikan komitmen untuk memberikan kepuasan pada pelanggan yang pada gilirannya akan menjadi sumber dinamisme penyempurnaan mutu jasa dan kinerja lembaga. Selain itu juga akan meningkatkan motivasi para karyawan untuk mencapai tingkat kinerja yang lebih baik dari pada sebelumnya.Garansi atau jaminan mutlak dirancang untuk meringankan risiko/kerugian pelanggan. Garansi tersebut menjanjikan kualitas prima dan kepuasan pelanggan, sehingga memaksa lembaga untuk memberikan yang terbaik dan meraih loyalitas pelanggan. Fungsi utama garansi adalah untuk

${ }^{6}$ Fandi Tjiptono, Prinsip-Prinsip Total Quality Service, (Yogyakarta: CV Andi Offset, 2005), hlm. 134-141. 
meminimalisir rasa kecewa para pelanggan atas segala sesuatu yang diberikan oleh lembaga yang bersangkutan. Suatu garansi yang baik harus memenuhi beberapa kriteria, diantaranya adalah:

1) Realistis dan dinyatakan secara spesifik

2) Sederhana, komunikatif, dan mudah dipahami

3) Tidak membebani pelanggan dengan syarat-syarat yang berlebihan

4) Berfokus pada kebutuhan pelanggan

5) Memberikan standar kinerja yang jelas

\section{d. Strategi penanganan keluhan yang efisien}

Penanganan keluhan yang baik memberikan peluang untuk mengubah seorang pelanggan yang tidak puas menjadi pelanggan yang puas, manfaat lainnya antara lain:

1) Penyedia jasa memperoleh kesempatan lagi untuk memperbaiki hubungan dengan pelanggan yang kecewa

2) Penyedia jasa bisa terhindar dari publistas negatif

3) Penyedia jasa akan mengetahui aspek-aspek yang perlu dibenahi dalam pelayanannya pada saat ini

4) Penyedia jasa akan mengetahui sumber masalah operasinya

5) Pegawai dapat termotivasi untuk memberikan pelayanan yang berkualitas lebih baik

Proses penanganan keluhan yang efektif dimulai dari identifikasi dan penentuan sumber masalah yang menyebabkan pelanggan tidak puas dan mengeluh. Langkah ini merupakan langkah yang sangat penting, karena menentukan efektivitas langkah-langkah selanjutnya. Sumber masalah ini perlu diatasi dan ditindaklanjuti agar dimasa mendatang tidak timbul masalah yang sama.

Ketidakpuasan bisa semakin besar apabila pelanggan yang mengeluh merasa keluhannya tidak diselesaikan dengan baik. Yang penting bagi pelanggan adalah bahwa pihak lembaga harus menunjukan rasa perhatian, keprihatinan, dan penyesalan terhadap kecewanya pelanggan dan berusaha memperbaiki situasi. Oleh karena itu para karyawan/pegawai perlu dilatih dan diberdayakan untuk mengambil keputusan dalam rangka menangani situasi-situasi seperti itu. 
Ada empat aspek penting dalam penanganan keluhan, yaitu sebagai berikut: ${ }^{7}$

1) Empati pada pelanggan yang marah

2) Kecepatan dalam penanganan keluhan

3) Kewajaran atau keadilan dalam memecahkan permasalahan atau keluhan

4) Kemudahan bagi pelanggan untuk menghubungi perusahaan

Jika aspek penting tersebut diatas dilaksanakan dengan baik maka para pelanggan tidak timbul kekecewaan yang lain.

\section{e. Strategi peningkatan kinerja lembaga}

Hal ini meliputi berbagai upaya seperti melakukan pemantauan dan pengukuran kepuasan pelanggan secara terus menerus dan berkesinambungan, memberikan pendidikan dan pelatihan menyangkut komunikasi, salesmanship, dan public relation kepada pihak manajemen dan karyawan, memasukkan unsur kemampuan untuk memuaskan pelanggan kedalam sistem penilaian prestasi karyawan.

\section{f. Menerapkan Quality Function Deployment (QFD)}

QFD yaitu praktik untuk merancang suatu proses sebagai tanggapan terhadap kebutuhan pelanggan. ${ }^{8} \mathrm{QFD}$ dapat didefinisikan sebagai suatu proses atau mekanisme terstruktur untuk menentukan kebutuhan pelanggan dan menerjemahkan kebutuhan-kebutuhan itu kedalam kebutuhan teknis yang relevan, dimana masing-masing area fungsional dan level organisasi dapat mengerti dan bertindak.

QFD apabila diterapkan secara tepat akan memberikaan hasilhasil sebagai berikut:

1) Meningkatkan efektivitas komunikasi diantara departemendepartemen

2) Kebutuhan pelanggan dibawa melalui proses langsung ke operasional

3) Lebih sedikit perubahan-perubahan sistem yang terjadi hlm. 132.

${ }^{7}$ M. Nur Nasution, Manajemen Jasa terpadu (Total Service Management), ${ }^{8}$ Fandy Tjiptono, Prinsip-Prinsip Total Quality Service, hlm. 141. 
4) Meningkatnya kualitas sistem

5) Rendahnya biaya yang digunakan

6) Hemat waktu

7) Identifikasi dan penyelesaian kembali dari kebutuhankebutuhan yang bertentangan dari berbagagi pelanggan. ${ }^{9}$

Pekerjaan dari tim QFD adalah mendengarkan suara dari pelanggan. Isu-isu utama dalam suara pelanggan adalah:

1) Memikirkan kebutuhan dan keinginan pelanggan

2) Sebagai titik awal untuk merancang produk dan proses operasional

3) Berfokus dan mengendalikan proses

4) Harus dimonitor secara terus menerus

5) Memberikan basis untuk pengukuran kritis.

Tercapainya kepuasan pemustaka sebagai pelanggan merupakan sebuah keniscayaan yang harus diwujudkan oleh pengelola perpustakaan. Oleh sebab itulah maka perlu terobosan alternatif untuk membantu mempermudah mewujudkannya. Salah satu dari beberapaalternatif adalah menggunakan media sosial yang dikelola dengan sistem manajemen yang baik.

\section{Manajemen Pemanfaatan Media Sosial}

Perkembangan teknologi mendasari lahirnya media sosial yang saat ini mengubah perilaku komunikasi dan sosial dalam masyarakat profesi. Munculya media sosial menjadikan komunikasi dapat dilakukan seperti tanpa batas jarak dan waktu. Dengan media sosial dapat dimungkinkan membuat komunitas-komunitas pemustaka dan pustakawan dengan dapat saling support atau sharing, dengan berbagai kelebihan-kelebihan tersebut, media sosial saat ini marak di jadikan tempat pemustaka dan pustakawan untuk membentuk group atau komunitas dengan berbagai tujuan, tujuan tersebut diantaranya sebegai ajang silaturahmi, komunikasi, sharing dan juga pengembangan diri. Situs jejaring sosial didefinisikan sebagai layanan berbasis web yang memungkinkan individu untuk membangun profil publik, 2008), Hlm. 42

9 Vincent Gaspersz, Total Quality Management, (Jakarta: Gramedia, 
dengan jejaring sosial dapat diatur daftar pengguna lain dengan siapa mereka berbagi koneksi, melihat dan menunjukkan daftar koneksi yang dimiliki dan yang dibuat oleh orang lain dalam sistem. ${ }^{10}$ Powel mendefinisikan jaringan media sosial sebagai sebuah komunitas yang terhubung melalui persahabatan, nilai-nilai, hubungan, ide dan pekerjaan. ${ }^{11}$ Seufert mendefinisikan situs jejaring sosial sebagai sejumlah orang, sumber daya yang terhubung untuk mengumpulkan pengetahuan untuk tujuan menciptakan suatu nilai. Konsep jejaring sosial adalah salah satu dari alat-alat Web 2.0, yang juga membentuk dasar perpustakaan 2.0.

Andreas Kaplan dan Michael Haenlein mendefinisikan media sosial sebagai "sebuah kelompok aplikasi berbasis internet yang dibangun atas dasar ideologi dan teknologi Web 2.0, dan yang memungkinkan pertukaran informasi. ${ }^{12}$ Dari berbagai definisi diatas dapat disimpulkan bahwa media sosial adalah web platform di mana orang-orang dari budaya yang berbeda pengaturan dapat terhubung dan berinteraksi satu sama lainnya untuk bertukar informasi.

Penyajian informasi melalui media sosial telah dijalankan oleh hampir setiap perpustakaan di perguruan tinggi. Namun sajiannya masih terbatas, dan terdeteksi banyak yang menyajikan informasi secara insidental. Belum dikelola secara reguler dengan manajemen yang optimal. Oleh karena itu, dalam hal ini sebagai bagian dari usaha mengoptimalkan peran media sosial untuk mewujudkan perpustakaan yang mudah diakses dimanapun, maka perlu standardisasi manajemen pemanfaatan media sosial, sehingga akan tercapai kepuasan pemustaka.

Standar nasional perpustakaan perguruan tinggi harus dipenuhi antara lain, standar koleksi, standar gedung, standar tenaga

${ }^{10}$ Boyd, D.M., \& Ellison, N.B. (2007). Social network sites: Definition, history, and scholarship. Journal of Computer-Mediated Communication, 13(1), 210-230.

11 Powell, Juliette (2009) 33 million People in the Room: how to create, influence, and run asuccessful Business with Social networking. Pearson Education, Inc.http://33millionpeople.com/wpcontent/uploads/2012/09/33MillionPeopleInT heRoom

${ }^{12}$ Kaplan, Andreas M.; Michael Haenlein [2010] "Users of the world, unite! The challenges and opportunities of Social Media”. Business Horizons 53(1): 59-68 
perpustakaan, standar teknis perpustakaan, standar layanan, dan standar manajemen perpustakaan. Standar yang terkahir (manajemen perpustaaan) menjadi pekerjaan rumah bagi pengelola perpustakaan, agar dunia media sosial dapat dikelola dengan optimal, agar fungsi manajemen terukur dan dapat mencapai target kepuasan pemustaka.

\section{a. Manajemen Perpustakaan}

Manajemen berasal dari bahasa Latin, yaitu dari kata manus yang berarti tangan dan agere (melakukan). Tergabung menjadi managere yang berarti menangani. Managere diterjemahkan ke dalam bahasa Inggris to manage, management, manager. Dan diterjemahkan ke dalam bahasa Indonesia menjadi manajemen (pengelolaan). ${ }^{13}$

Dalam sebuah buku yang ditulis oleh Didin Hafidhuddin dan Hendri Tanjung disebutkan bahwa "Management means organizing, handling, controling, and directing a particular thing or affair. ${ }^{14}$ Manajemen berarti mengorganisasikan, mengendalikan, mengontrol, dan pelangsungan sesuatu urusan.

Luther Gulick dikutip oleh Hani Handoko mendefinisikan manajemen sebagai suatu bidang ilmu pengetahuan (science) yang berusaha secara sistematis untuk memahami mengapa dan bagaimana manusia bekerjasama untuk mencapai tujuan dan membuat sistem kerjasama ini lebih bermanfaat bagi kemanusiaan. ${ }^{15}$ George R. Terry menyebutkan bahwa manajemen adalah suatu proses yang khas terdiri dari tindakan-tindakan perencanaan, pengorganisasian, penggerakan, dan pengendalian yang dilakukan untuk menentukan serta mencapai sasaran yang telah ditentukan melalui pemanfaatan sumber daya manusia dan sumber-sumber daya lainnya. ${ }^{16}$

Dari definisi-definisi diatas dapat disimpulkan bahwa pengertian manajemen adalah suatu proses pengelolaan dan pemanfaatan sumber daya manusia dan sumber daya lainnya untuk

${ }^{13}$ Husaini Usman, Manajemen: teori, Praktik dan Riset Pendidikan, Ed. 4, Cet. 2, (Jakarta: Bumi Aksara, 2014) Hlm. 5-6

14 Didin Hafidhuddin dan Hendri Tanjung, Shariah Prinsiples On Management Inpractice,(Jakarta: Gema Insani, 2006), hlm. 2.

15 T. Hani Handoko, Manajemen, (Yogyakarta: BPFE, 2003), hlm. 11.

16 Ara Hidayat dan Imam Machali, Pengelolaan Pendidikan: Konsep, Prinsip dan Aplikasi Dalam Mengelola Sekolah dan Madrasah, (Bandung: Pustaka Educa, 2010), hlm. 3. 
dapat mencapai tujuanorganisasi/lembaga yang telah ditentukan dengan efektif dan efisien.

Selanjutnya definisi perpustakaan berasal dari kata dasar pustaka, menurut kamus besar Bahasa Indonesia Pustaka artinya kitab. Sedangkan definisi Perpustakaan menurut istilah adalah suatu unit kerja dari suatu badan atau lembaga tertentu yang mengelola bahan pustaka baik berupa buku-buku, maupun bukan berupa buku yang diatur secara sistematis menurut aturan tertentu sehingga dapat digunakan sebagai sumber informasi oleh setiap pemakainya. ${ }^{17}$

Dari beberapa pengertian tersebut di atas dapat jelaskan bahwa manajemen perpustakaan adalah proses pemanfaatan sumber daya manusia dan sumber daya lainnya untuk dapat mengelola bahan pustaka baik berupa buku maupun non buku sehingga dapat digunakan sebagai bahan informasi oleh setiap pemustaka.

\section{b. Manajemen Pemanfaatan Media Sosial}

Fungsi manajemen khususnya dalam pemanfaatan media sosial diantaranya adalah planning, organizing, actuating, controlling dan evaluating. Seluruhnya menjadi satu kesatuan fungsi manajemen yang berpeluang membantu untuk mencapai tujuan organisasi secara optimal. Agar supaya media sosial benar-benar dapat difungsikan untuk membantu pelayanan perpustakaan secara maksimal, dan dapat dimanfaatkan secara mudah dari seluruh dunia, maka perlu dikelola secara menyeluruh.

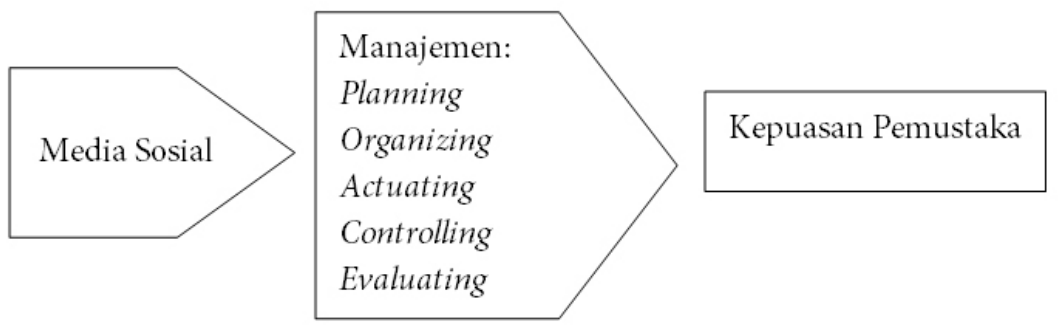

Gambar 1: Strategi Kepuasan Pemustaka Melalui Manajemen Pemanfaatan Media Sosial

${ }^{17}$ Ibrahim Bafadal, Pengelolaan Perpustakaan Sekolah, (Jakarta: PT Bumi Aksara, 2005), hlm. 3. 


\section{1) Planning dalam Pemanfaatan Media Sosial}

Planning (Perencanaan) adalah pengambilan keputusan. Perencanaan meliputi: pemilihan atau penetapan tujuan-tujuan organisasi, penentuan strategi, kebijakan, proyk, program, prosedur, metode, sistem, anggaran dan standar yang dibutuhkan untuk mencapai tujuan. Perencanaan tidak dapat lepas dari unsur pelaksanaan, pengawasan, pemantauan, penilaian dan pelaporan. ${ }^{18}$

Dalam pngertian lain bahwa perencanaan adalah memilih dan menghubungkan fakta dan membuat serta menggunakan asumsi-asumsi mengenai masa yang akan datang dengan jalan mengambarkan dan merumuskan kegiatan-kegiatan yang diperlukan untuk mencapai hasil yang diinginkan dengan efektif dan efisien. ${ }^{19}$ Perencanaan merupakan titik awal kegiatan perpustakaan dan harus disusun dengan baik. Perencanaan berguna untuk memberikan arah, menjadi standar kerja, memberikan karangka pemersatu dan membantu memperkirakan peluang. Dengan demikian, perencanaan itu merupakan langkah awal sebelum melakukan fungsi-fungsi manajemen yang lain. ${ }^{20}$

Media sosial yang telah direncanakan sebagai bagian dari sarana untuk mencapai target organisasi, maka perlu penyusunan perencanaan yang tercakup siapa (who) yang bertanggung jawab terhadap pemanfaatan media sosial, apa (what) yang dilakukan dengan media sosial, bagaimana (how) cara melaksanakan pemanfaatan media sosial, kapan (when) melaksanakannya, dimana (where) itu dilakukannya, mengapa ( why) media sosial tertentu dipilih dan berapa anggaran yang diperlukan dalam penerepan media sosial tersebut.

2) Organizing Pemanfaatan media sosial

Organisasi berasal dari bahasa Latin, organum organum yang berarti alat, bagian, anggota badan. ${ }^{21}$ Pengorganisasian merupakan

${ }^{18}$ Husaini Usman, Manajemen: teori, Praktik dan Riset Pendidikan, Ed. 4, Cet. 2, (Jakarta: Bumi Aksara, 2014) Hlm. 77.

${ }_{19}$ Malayu Hasibuan, Manajemen Sumber Daya Manusia, (Jakarta: Bumi Aksara, 2008), hlm. 249.

${ }^{20}$ Lasa HS, Manajemen Perpustakaan Sekolah, (Yogyakarta: Pinus Book Publisher, 2007), hlm. 23.

${ }^{21}$ Husaini Usman, Manajemen: teori, Praktik dan Riset Pendidikan, Ed. 4, Cet. 2, (Jakarta: Bumi Aksara, 2014) Hlm. 77. 
penyatuan langkah dari seluruh kegiatan yang akan dilaksanakan. Penyatuan langkah ini sangat penting, agar tidak terjadi tumpang tindih dalam pelaksanaan tugas. Proses mengorganisasikan sebuah perpustakaan akan berjalan dengan baik apabila memiliki SDM, sumber dana, prosedur, dan adanya koordinasi yang baik serta pengarahan pada langkah-langkah tertentu. Dalam sistem pengorganisasian perpustakaan perlu diperhatikan elemen-elemen perpustakaan yang antara lain terdiri dari kegiatan, SDM, sistem, sumber informasi, sarana dan prasarana serta dana. Pengorganisasian perpustakaan merupakan tanggung jawab pegawai perpustakaan. Pengorganisasian merupakan aspek manajemen yang menyangkut penyusunan organisasi manusia dan bahan atau materi. Kegiatannya meliputi:

1. Pengaturan pelayanan peminjaman yang efisien pengguna perpustakaan.

2. Menyediakan sistem yang efisien mengenai pelayanan pemesanan bahan atau koleksi yang ada di perpustakaan dan memberikan sistem peminjaman silang layan (inter-library loon) untuk bahan-bahan yang berada di perpustakaan lain.

3. Memberikan sistem yang fleksibel bagi peserta didik, baik perorangan maupun kelompok, serta staf pengajar untuk menggunakan perpustakaan sekolah untuk tujuan proses belajar mengajar.

4. Menjalankan suatu sistem yang memungkinkan sumbersumber informasi dalam bentuk perangkat keras (jika dipusatkan) dapat digunakan dengan cara yang sehemat dan seefisien mungkin keberbagai tempat di sekolah.

5. Mengatur produksi sumber belajar di dalam perpustakaan sekolah.

6. Mengawasi dan mengatur pekerjaan bagi pustakawan atau staf perpustakaan yang lain. ${ }^{22}$

Sebagaimana diketahui bahwa organisasi timbul karena adanya kebutuhan untuk mengumpulkan orang-orang dalam rangka mencapai tujuan bersama sehingga terjadi pembagian kerja. Hal ini akan efektif

${ }^{22}$ Sulistia dkk, Manajemen Perpustakaan Sekolah, (Universitas Terbuka, Depdikbud, 1995),hlm. 27-28. 
apabila di alam organisasi tersebut terdapat struktur organisasi yang jelas, baik secara mikro maupaun makro. Struktur organisasi merupakan mekanisme formal dalam pengelolaan organisasi itu sendiri yang didalamnya terdapat pembagian tugas, wewenang, dan tanggung jawab yang berbeda-beda. Hal ini akan tampak jelas apabila disusun pada suatu bagan formal organisasi. Melalui bagan ini akan tampak fungsi-fungsi, pembagian unit, dan posisi organisasi serta ditunjukan hubungan antara unit-unit tersebut.

Sistem pengorganisasian yang proporsional pada perpustakaan akan menumbuhkan kreatifitas karena adanya kelancaran komunikasi dan interaksi antarindividu dan antar unit kerja. Dengan adanya komunikasi yang baik diharapkan akan menjadikan organisasi perpustakaan yang solid dan tujuan serta sasarannya dapat tercapai secara optimal. Agar organisasi perpustakaan berjalan dengan baik, ada beberapa prinsip yang menjadi landasan geraknya, antara lain: ${ }^{23}$

Perumusan tujuan, tujuan organisasi harus jelas dan diketahui oleh seluruh elemen yang terkait dalam organisasi itu. Dengan tujuan tertentu, aktifitas-aktifitas yang dilakukan akan mengarah pada tujuan yang telah dirumuskan.

Pembagian kerja, Untuk mencapai efektivitas dan efisiensi, perlu adanya pembagian tugas yang jelas. Tanpa pembagian tugas yang jelas maka akan terjadi tumpang tindih pekerjaan dan dari sini akan terjadi pemborosan.

Pembagian wewenang, dengan kekuasaan yang jelas pada masing-masing orang atau kelompok dalam organisasi, maka dapat dihindarkan terjadinya benturan kepentingandan tindakan. Hal itu dimungkinkan karena setiap orang akan mengetahui batas-batas wewenang untuk bertindak.

Kesatuan komando, dalam sistem organisasi yang baik harus ada kesatuan komando/perintahagar tidak terjadi kebingungan ditingkat pelaksana. Oleh karena itu dalamsistem organisasi perpustakaan perlu dihindarkan adanya dualismepengaruh dan kekuasaan dalam berbagai 2008), hlm, 277.

${ }^{3}$ Lasa HS, Manajemen Perpustakaan, (Yogyakarta: GAMA MEDIA, 
tingkat manajerial, baik padamanajer puncak, manajer menengah, maupun manajer lini.

Koordinasi, Koordinasi merupakan proses pengintegrasian tujuan pada satuan-satuanyang terpisah dalam suatu lembaga untuk mencapai tujuan organisasisecara efisien. Koordinasi ini sangat penting bagi suatu lembaga untukmenyatukan langkah, mengurangi benturan tugas, dan mengurangi konflikinternal.

Kehadiran pustakawan diperlukan dalam mengelola perpustakaan,karena pustakawan merupakan tenaga ahli dan profesional yang dapatmerealisasikan tujuan perpustakaan yang telah ditetapkan. Sebaliknya suatuurusan tidak akan menemui kesuksesan apabila dikelola kepada selainahlinya.

3) Actuating dalam Pemanfaatan Media Sosial

Menurut Terry (1997) penggerakan (actuating) adalah merangsang anggota-anggota kelompok melaksanakan tugas-tugas dengan antusias dan kemauan yang baik. Menggerakkan adalah tugas pemimpin dan kepemimpinan. Menggerakkan menurut Keith Davis (1972) ialah kemampuan pemimpin membujuk orang-orang mencapai tujuan-tujuan yang telah ditetapkan dengan penuh semangat.

Fungsi penggerakkan merupakan fungsi manajerial yang sangat penting, karena secara langsung berkaitan dengan manusia dengan segala jenis kepentingan dan keutuhannya. Dengan demikian, penggerakkan merupakan tanggung jawab pimpinan perpustakaan, dan peran seorang pemimpin diperlukan dalam mendorong staf yang dipimpinnya.

Pimpinan dalam sebuah perpustakaan dapat menggerakkan staf untuk dapat menggerakkan lebih semangat dan menunjukkan akan pentingnya media sosial saat ini bagi kaum muda, sehingga perpustakaan dapat memanfaatkan momen tersebut untuk menyusup untuk memmpengaruhi hal positif melalui media sosial seperti facebook dan lainnya.

4) Controlling dalam Pemanfaatan Media Sosial

Pelaksanaan tugas, kekuasaan, dan tanggung jawab dalam perpustakaan perlu adanya pengawasan, yang pada umumnya 
merupakan coercion atau compeling artinya proses yang bersifat memaksa agar kegiatan pelaksanaan dapat disesuaikan dengan rencana. ${ }^{24}$ Good control is that one that was already built in a program planned. ${ }^{25}$ Pengawasan yang baik adalah salah satu persiapan dalam pembentukan program perencanaan. Prihal pengawasan hendaknya direncanakan dengan baik, supaya dapat mencapai tujuan dengan maksimal. Pengawasan dikaitkan dengan upaya untuk mengendalikan dan membina sebagai upaya pengendalian mutu. Melalui pengawasan yang efektif, roda organisasi, implementasi rencana, kebijakan dan upaya pengendalian mutu dapat dilaksanakan dengan lebih baik.

Pengawasan terhadap perpustakaan sekolah dimaksudkan untuk mengetahui efektifitas perpustakaan. Untuk mengetahui efektifitas ini perlu diketahui dulu tentang indikator kinerja perpustakaan. Kinerja perpustakaan adalah efektifitas jasa yang disediakan perpustakaan dan efisiensi sumber daya yang digunakan untuk menyiapkan jasa.

Untuk menilai efektifitas kinerja perpustakaan dikenal dengan beberapa teori yaitu konsep kriteria. Dengan konsep tersebut memungkinkan untuk menilai efektifitas perpustakaan sekolah melalui pengukuran terhadap akses, biaya, kepuasan pemakai, rasio biaya, keuntungan dan penggunaan. ${ }^{26} \mathrm{Hal}-\mathrm{hal}$ yang harus diperhatikan dalam aspek pengawasan di perpustakaan di antaranya sebagai berikut:

1. Selalu menyadari tujuan yang sedang dilaksanakan.

2. Menghindari kegiatan yang tidak efisien, misalnya dalam sistem pemilihan perangkat keras.

3. Evaluasi terhadap pelayanan yang telah dilakukan.

Dalam melaksanakan pengawasan dapat dilakukan dengan cara preventif dan korektif. Pengawasan preventif adalah pengawasan yang mengantisipasi terjadinya penyimpangan-penyimpangan, sedangkan pengawasan korektif baru bertindak apa bila terjadi variasi-variasi dari hasil yang diinginkan.

${ }^{24}$ Nanang Fatah, Landasan Manajemen Pendidikan, (Bandung: Remaja Rosdakarya, 2006), hlm.102.

${ }_{25}$ Didin Hafidhuddin dan Hendri Tanjung, Shariah Prinsiples On Management Inpractice, (Jakarta: Gema Insani, 2006), hlm. 179.

${ }^{26}$ Lasa HS., Manajemen Perpustakaan Sekolah, hlm. 34. 
Pengawasan yang merupakan bagian atau unsur dari mekanisme kegiatan suatu organisasi dimaksudkan untuk mencegah, menghilangkan dan menghindarkan atau mengurangi terjadinya halhal tentang kegagalan, kerugian, penyimpangan, kebocoran, kesalahan, penyalahgunaan jabatan/wewenang dan keterlambatan/hambatan

Dalam melaksanakan fungsi pengawasan perlu dipahami terlebih dahulu konsep perencanaan, standar evaluasi, dan sistem pengawasan. Oleh karena itu perlu diperhatikan sejauh mana kesesuaian perencanaan tentang kegiatan, SDM, sumber informasi, sistem, anggaran, dan sarana prasarana perpustakaan dengan realisasi pada waktu tertentu. Apabila dalam pengawasan itu perlu dilakukan tindakan korektif, maka tindakan ini harus segera diambil. Tindakan korektif ini bisa berupa mengubah standar yang telah direncanakan, memperbaiki pelaksanaan, mengubah cara pengukuran pelaksanaan, atau mengubah cara interpretasi atas penyimpangan-penyimpangan.

Kegiatan pengawasan juga memerlukan tindak lanjut, untuk melakukan usaha perbaikan terhadap kekurangan, kelemahan atau kesalahan suatu sistem. Misalnya jangka waktu peminjaman yang kurang cukup fleksibel. Step in the control process, there is agreement among students of management concerning the three elemental steps of the control process: 18

1. Estabilishing standards of performance (standar atau ukuran dalam elaksanaan, dalam hal ini sesuai dengan rencana yang telah ditentukan)

2. Measuring current performance in relation to estabilished standards (mengukur jalannya pelaksanaan yang berhubungan untuk menentukan standar atau ukuran)

3. Taking corrective action (mengambil tindakan korektif)

Tahapan-tahapan tersebut diatas hendakanya dapat dilakukan dengan cermat, agar dapat melaksankan proses controlling dengan baik. Dengan bantuan media sosial diharapkan proses kontrol terhadap pelayanan dan seberapa besar pengunjung/pemustaka setiap waktunya dalam menggunakan pelayanan perpustakaan dapat diketahui dengan mudah dan cepat. 


\section{5) Evaluating dalam Pemanfaatan Media Sosial}

Evaluasi adalah pembuatan pertimbangan menurut suatu perangkat kriteria yang disepakati dan dapat dipertanggungjawabk an. ${ }^{27}$ Sedangkan evaluasi di dalam perpustakaan adalah cara untuk mengontrol kualitas program pelayanan perpustakaan dengan cara memeriksa apabila semua aspek perpustakaan sudah mencapai standar yang diharapkan. Hasil dari evaluasi dapat digunakan sebagai bahan pertimbangan dalam melakukan langkah-langkah perbaikan dan sekaligus untuk merencanakan programprogram yang akan datang.

Aspek-aspek yang dievaluasi khususnya dalam pemanfaatan media sosial untuk pelayanan perpustakaan adalah sebagai berikut:

1. Penyajian informasi berupa evaluasi terhadap koleksi meliputi bagaimana cara-cara koleksi dipilih, diolah, diorganisasikan dan dilayankan kepada para pemustaka/pengunjung.

2. Penyajian informasi berupa pelayanan peminjaman koleksi, pelayanan referensi dan informasi, pelayanan bimbingan kepada pembaca dan pelayanan jam buka perpustakaan.

Kelima fungsi manajemen diatas merupakan rangkaian kegiatan untuk mencapai tujuan yang ditetapkan, sehingga dalam pelaksanaannya diperlukan usaha dan kerja sama dari pihak-pihak yang terkait. Berhasil atau tidaknya dalam pencapaian tujuan tesebut tergantung dari usahanya sendiri.

Pemanfaatan Media sosial akan dapat menginformasikan kepada pemustaka bahwa perpustakaan dalam pendidikan mempunyai fungsi lain sebagai berikut: ${ }^{28}$

1. Fungsi Informasi, perpustakaan menyediakan berbagai informasi yang meliputi bahan tercetak, terekam, maupun koleksi lainnya.

2. Fungsi pendidikan, perpustakaan menyediakan berbagai informasi sebagai sarana untukmencapai tujuan pendidikan.

\footnotetext{
${ }^{27}$ Nanang Fatah, Landasan Manajemen Pendidikan, (Bandung: Remaja Rosdakarya, 2006), hlm. 107.

${ }^{28}$ Darmono, Manajemen Dan Tata Kerja Perpustakaan sekolah, (Jakarta: PT Grasindo, 2004), Hlm. 3-4.
} 
3. Fungsi Kebudayaan, perpustakaan menyediakan berbagai informasi sebagai sarana untuk meningkatkan mutu kehidupan dengan memanfaatkan berbagai informasi sebagai rekaman budaya bangsa untuk meningkatkan taraf hidup dan mutu kehidupan manusia baik secara individu maupun kelompok, menumbuhkan budaya baca dikalangan pengguna, mendorong tumbuhnya kreativitas dalam kesenian.

4. Fungsi rekreasi, perpustakaan dapat menunjang berbagai kegiatan kreatif serta hiburan yang positif.

5. Fungsi penelitian, perpustakaan menyediakan berbagai informasi untuk menunjang kegiatan penelitian.

6. Fungsi deposit, perpustakaan berkewajiban menyimpan dan melestarikan semua bahan pustaka yang ada.

\section{c. Tujuan dan manfaat Manajemen Media Sosial untuk Perpustakaan}

Pada dasarnya tujuan dan manfaat manajemen adalah untuk mencapai dan meningkatkan efektivitas, efisiensi, dan produktivitas kerja dalam mencapai tujuan yang diinginkan. Efektivitas adalah suatu keadaan yang mengandung pengertian mengenai terjadinya efek atau hasil yang dikehendaki. ${ }^{29}$ Pendek katadisebut efektif jika suatu pekerjaan mencapai hasil dan tujuan secara optimal.

Sedangkan efisien adalah suatu pengertian yang menggambarkan perbandingan terbaik antara usaha dengan hasilnya (do things right). Perbandingan ini dapat dilihat dari dua hal. Pertama, dari hasil yaitu pekerjaan dikatakan efisien jika dengan usaha tertentu memberikan hasil yang maksimal, baik mengenai mutu maupun jumlah. Kedua, dari segi usaha, pekerjaan dikatakan efisien jika suatu hasil tertentu tercapai dengan suatu usaha minimal. Efisien umumnya merujuk kepada proses dengan pendayagunaan sumber daya, biaya, dll. Efisien ini berkaitan dengan produktivitas. Produktif adalah hasil yang dicapai dibandingkan dengan sumber daya (resources). Dalam pengertian lain produktif adalah rasio antara output dan input.

${ }^{29}$ Ara Hidayat dan Imam Machali, Pengelolaan Pendidikan: Konsep, Prinsip dan Aplikasi Dalam Mengelola Sekolah dan Madrasah, (Bandung: Pustaka educa, 2010), hlm. 17. 
Dalam kaitan dengan pengelolaan pemanfaatan media sosial, paling tidak ada beberapa hal yang dapat dicapai antara lain sebagai berikut:

1. Menghilangkan keterbatasan sarana dan prasana yang dimiliki perpustakaan, baik gedung maupun koleksi.

2. Mempercepat tersebarnya informasi tentang semua hal yang terkini tentang perpustakaan kepada pemustaka.

3. Memperluas terjangkaunya perpustakaan yang lokal sekalipun, untuk mendunia dan dapat diakses dari mana saja dan kapan saja.

\section{Implementasi Manajemen Pemanfaatan Media Sosial}

Langkah konkrit yang dapat dilakukan perpustakaan dalam menerapkan fungsi manajemen pemanfaatan media sosial demi kepuasan pemustaka antara lain: 1) melakukan pemilihan media sosial. 2) mengorganisasikan staff/SDM, sarana, waktu, kegiatan, dan koordinasi yang kontinyu. 3) penerapan layanan perpustakaan dengan media sosial yang telah dipilih sesuai kesepakatan. 4) melakukan pengawasan. 5) mengukur kepuasan pemustaka yang menggunakan media sosial.

1. Melakukan pemilihan media sosial Melakukan riset pasar $^{30}$ pemustaka terbanyak dalam menggunakan media sosial menjadi alasan utama dalam pemilihan media sosial yang tepat, apakah facebook, twitter dan lainnya. Kemudian melakukan analisis SWOT (strengh, Weakness, Opportunity and Treathment) untuk menentukan kebijakan selanjutnya.

2. Pengorganisasian Staff/SDM, sarana, waktu, kegiatan dan organisasi

Perpustakaan memilih dan mengorganisasikan SDM yang tepat, menyiapkan sarana baik Perangkat Hadrware, Software serta ruangan yang representatif.

${ }^{30}$ Edward Sallis, Total Quality Management in Education, Jogjakarta: IRCiSoD, 2012) Cet. XVI, hlm. 219. 
3. Penerapan pelayanan perpustakaan dengan media sosial Perpustakaan memastikan semua hasil digitalisasi buku, Jurnal dan karya ilmiah lainnya disajikan terlebih dahulu dalam website perpustakaan, kemudian me-link-kannya dengan media sosial yang telah dipilih.

4. Melakukan pengawasan terhadap layanan perpustakaan berbasis media sosial.

Pimpinan perpustakaan secara sendiri maupun membentuk tim pengawas untuk senantiasa mengontrol jalannya pelayanan perpustakaan memalui media sosial yang telah dipilih, secara periodik maupun sesuai jadwal yang telah disepakati pimpinan maupun tim pengawas.

5. Mengukur kepuasan pelanggan secara periodik terhadap pemustaka.

Pengukuran terhadap pemustaka untuk mengetahui tingkat kepuasannya dapat dilakukan dengan teknik wawancara maupun koesioner. Wawancara atau interview/koesioner lisan adalah sebuah dialog yang dilakukan melalui wawancara untuk memperoleh informasi dari pihak yang diwawancarai. ${ }^{31}$ Teknik koesioner merupakan angket berisi daftar pertanyaan yang ditujukan kepada responden, yakni pemustaka. Kedua teknik tersebut dapat dilakukan terhadap pemustaka baik melalui media sosial maupun langsung bertatap muka.

\section{Simpulan}

Media sosial telah menjadi aktifitas komunikasi yang efektif bagi sebagian besar umat manusia akhir-akhir ini, namun komunikasi yang dibangun masih sedikit ranah keilmuannya. Disisi lain kebutuhan pemustaka akan perpustakaan semakin meningkat sementara akses langsung semakin terbatas di sarana maupun waktu, oleh karena itu saatnya perpustakaan memasuki dunia media sosial untuk memperluas akses dan meningkatkan kualitas pelayanan kepada pemustaka.

${ }^{31}$ Suharsimi Arikunto, Prosedur Penelitian Suatu Pendekatan Praktek, (Jakarta: Rineka Cipta, 2002), hlm.107. 
Perpustakaan dapat memanfaatkan mesia sosial dengan optimal melalui fungsi menajamen/pengelolaan seperti planning, organizing, actuating, controlling dan evaluating dalam memaksimalkan pemanfaatan media sosial.

Implementasi pemanfaatan media sosial oleh perpustakaan dapat dilakukan dengan 1) pemilihan media sosial yang tepat 2) mengorganisasikan staff/SDM, sarana, waktu dan koordinasi 3) pelaksanaan penerapan layanan perpustakaan dengan media sosial 4) melakukan pengawasan layanan 5) melakukan evaluasi terhadap tingkat kepuasan pemustaka.

Dengan memanfaatkan media sosial yang dikelola dengan baik, diharapkan keterbatasan sebuah perpustakaan dapat diatasi, misalnya keterbatasan koleksi buku, gedung, dan waktu kunjung, karena seluk beluk informasi dari dalam perpustakaan dapat diakses melalui media sosial kapan dan dimana saja secara efektif dan efisien. 


\section{DAFTAR PUSTAKA}

Arikunto, Suharsimi, Prosedur Penelitian Suatu Pendekatan Praktek, Jakarta: Rineka Cipta, 2002.

Bafadal, Ibrahim, Pengelolaan Perpustakaan Sekolah, Jakarta: PT Bumi Aksara, 2005

Boyd, D.M., \& Ellison, N.B. 2007. Social network sites: Definition, history, and scholarship. Journal of Computer-Mediated Communication, 13(1), 210-230.

Darmono, Manajemen Dan Tata Kerja Perpustakaan sekolah, Jakarta: PT Grasindo, 2004.

Fatah, Nanang, Landasan Manajemen Pendidikan, Bandung: Remaja Rosdakarya, 2006.

Gaspers, Vincent, Total Quality Management, Jakarta: Gramedia, 2008.

Handoko, T. Hani, Manajemen, Yogyakarta: BPFE, 2003.

Hasibuan, Malayu, Manajemen Sumber Daya Manusia, Jakarta: Bumi Aksara, 2008.

Hidayat, Ara dan Imam Machali, Pengelolaan Pendidikan: Konsep, Prinsip dan Aplikasi Dalam Mengelola Sekolah dan Madrasah, Bandung: Pustaka Educa, 2010.

Kaplan, Andreas M.; Michael Haenlein. 2010. «Users of the world, unite! The challenges and opportunities of Social Media». Business Horizons 53(1): 59-68

Lasa HS, Manajemen Perpustakaan Sekolah, Yogyakarta: Pinus Book Publisher, 2007.

Lasa HS, Manajemen Perpustakaan, Yogyakarta: GAMA MEDIA, 2008.

Nasution, M. Nur, Manajemen Jasa terpadu (Total Service Management), Bogor: Ghalia Indonesia, 2004.

Powell, Juliette .2009. 33 million People in the Room: how to create, influence, and run a successful Business with Social networking. 
Pearson Education, Inc. http://33millionpeople.com/ wpcontent/

Purnomowati, S.. Mengukur kinerja perpustakaan. BACA 252000 $(3 \& 4)$.

Sallis, Edward, Total Quality Management in Education, Cet. XVI, Jogjakarta: IRCiSoD, 2012

Sulistia dkk, Manajemen Perpustakaan Sekolah, Universitas Terbuka, Depdikbud, 1995.

Tjiptono, Fandi, Prinsip-Prinsip Total Quality Service, Yogyakarta: CV Andi Offset, 2005.

Usman, Husaini. Manajemen: teori, Praktik dan Riset Pendidikan, Ed. 4, Cet. 2, Jakarta: Bumi Aksara, 2014. 
